\title{
Impact of Macroeconomic Variable and Global Indices on Islamic Stock Index: The Case Indonesia
}

\author{
Muhammad Sanusi ${ }^{1}$, Jihad $^{1}$, Imron Mawardi ${ }^{1}$
}

${ }^{1}$ Fakultas Ekonomi dan Bisnis, Universitas Airlangga, Indonesia

*sanusimuhammad171@gmail.com

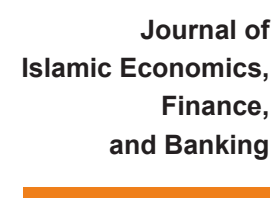

Vol. 4, No. 1, June 2021, pp. 45-58, ISSN p:2622-4755 e:2622-4798

\begin{abstract}
Introduction to The Problem: The movement of the Islamic stock index can be influenced by changes in domestic macroeconomic conditions, not only domestic macroeconomics but also influenced by the stock markets of other countries.
\end{abstract}

Purpose/Objective Study: The main objective of this study is to analyze the influence of the domestic macroeconomic and global stock indices on the Indonesian sharia stock index.

Design/Methodology/Approach: This study uses a quantitative methodology with secondary data. The data sample method is a saturated sample that all members of the population are used to as the research sample. The type of research data is a monthly time series with a time period from May 2011 - July 2019, the selection of the Vector Error Correction Model (VECM) research method based on the stationarity of the data on the first difference and the existence of cointegration models.

Findings: The results showed in the short term all variables did not show a significant effect. In the long run, interest rates have a negative effect, while the exchange rate shows a positive effect on the movement of Islamic stock price indexes. Global stock indices such as the Shanghai Stock Exchange Index show a negative effect, and the Standard \& Poor's 500 index shows a positive effect. While the Nikkei 225 index did not show a significant effect on the Indonesian Islamic stock index.

Paper Type: Research Article

Keywords: Domestic macroeconomic; global stock index; Indonesian sharia stock index; VECM.

Ihtifaz: Journal of Islamic Economics, Finance, and Banking

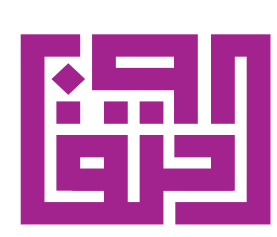

IHTIFAZ

UNIVERSITAS AHMAD DAHLAN Kampus 4 Universitas Ahmad Dahlan Jl. Ringroad Selatan, Tamanan Banguntapan, Bantul Yogyakarta 55191 


\section{INTRODUCTION}

In addition to banking, the capital market plays a very important IHTIFAZ - JIEFB role as an investment instrument. Investments in the capital market are closely linked to securities instruments, while the traded securities are shares, bonds, investment funds, warrants and others. The focus in this study is on equities, so when investing in the capital market the value of stock prices becomes an important consideration. According to Antonio et al., (2013) the price of shares on the capital market is not only influenced by internal companies, but can also be influenced by macroeconomic variables. Stable macroeconomic conditions ensure that investors feel safe and comfortable investing their funds.

The relationship between investment and risk has a very close relationship, any economic activity such as investment will not be separated from risk, so the risk cannot be avoided but can only be minimized. Investments in the capital market can be influenced by various risks due to changes in domestic macroeconomic conditions (economic growth, inflation, exchange rates, interest rates) and global macroeconomic conditions (economies from other countries).

Indonesia is a country with a majority of Muslims. In Islam all aspects of life are regulated, including spiritual, social, political and economic aspects. Allah SWT said in Surah Al-maidah ayat 3 " This day have I perfected your religion for you and completed My favor unto you, and have chosen for you as religion al-Islam". As a Muslim, he must of course guard against financial transactions that deviate from Islamic doctrine. Investments are part of the economy and must be in accordance with Islamic teaching in their implementation.

Basic principles in Islam must be avoided for activities that contain elements of maysir, gharar, riba, ihtikar. Moreover, it must be avoided against illegal substances (alcohol, pork and tobacco). So, it is very important for a Muslim to invest in sharia investment products. As a form of concern for Muslims who want to invest in accordance with Sharia, an investment product was issued in 1997, namely a Shariah investment fund by Danareksa Investment Management (DIM). The launch of the Jakarta Islamic Index around 2000 was based on a collaboration between Danareksa Investment Management (DIM) and the Jakarta Stock Exchange (JSX) as the first Islamic index in Indonesia. In 2011, the Indonesia Stock Exchange published the Indonesian Sharia Stock Index (ISSI), which includes all Sharia shares that are included in the Daftar Efek Syariah (DES).

The Islamic capital market shows a positive trend and an increase in market share can be seen in the number of lists of Islamic stock and market capitalization. Based on Sharia stock statistics published by the Otoritas Jasa Keuangan (OJK) that since ISSI was first introduced in 2011, the number of shares entered into the DES was 253 and reached 419 from July 2019, a growth of around $65.61 \%$. The market 
capitalization in 2011 was Rp 1,968 trillion until July 2019 Rp 3,741 trillion, a growth of $90.01 \%$.

Journal of

Islamic Economics,

Finance,

and Banking economy. According to Ameer (2006) there was integration between the stock markets. First, there is the phenomenon of correlation between the stock market and the interest rates for oil and other commodities. Secondly, the openness of the stock market to offer returns to foreign investors is due to portfolio diversification between the stock markets.

According to Murhadi (2009) a country with a strong economy can influence the economies of other developed and developing countries. Countries with economic power such as America, Japan and China dominate the global economy. The economic conditions of these countries are important information for other countries such as Indonesia. In addition, these three countries make the world's largest contribution to GDP, capitalization of the capital market and the export destination non-migas from Indonesia.

The capital market is one of the important indicators in a country's economy, so the capital market can be a measure of the country's economic success. To find out the impact of the economies of the three largest economies in the world (America, China, Japan), three stock market indices are chosen. There are three indices that serve as benchmarks for the United States, namely DJIA, S\&P 500 and Nasdaq. The index used in this study is the S\&P 500 Index because all shares are included in the DJIA category. For Japan, the index used is the Nikkei 225 index and China uses the Shanghai Stock Exchange.

The performance of the Sharia capital market reflected in the Indonesian Sharia Stock Index cannot be avoided due to risks due to changes in macroeconomic variables. According to Antonio et al., (2013) in accordance with the conditions of economic globalization, stock prices are not only influenced by domestic macro conditions, but also by global macro conditions. So, the focus of this research is to view and analyze the influence of domestic macroeconomic factors and global indices on the Indonesian Sharia Stock Index.

There are various macroeconomic variables and global indices that are used as variables that influence price movements such as interest rates, exchange rates, (Antonio dkk., (2013); Sakti \& Harun (2013); Bekhet \& Matar (2013); Artini dkk., (2017); Oktarina, (2017); Pratama \& Azzis, (2018); Wei dkk., (2019); Mawardi dkk., (2019)), oil price variable (Antonio dkk., (2013); Oktarina, (2017); Wei dkk., (2019)), Composite Index variable (Antonio dkk., (2013); Ahmed \& Huo, (2019); Mohti dkk., (2019); Wei dkk., (2019); Oktarina, (2017); Artini dkk., (2017)).

\section{Exchange rate}

The exchange rate is a macroeconomic indicator that is a major concern regarding its impact on the national economy, including the
Vol. 4, No. 1, June 2021, pp. 45-58, ISSN p:2622-4755 e:2622-4798 
capital market. An unstable exchange rate has an impact on the capital exit so that it can affect stock prices (Kyereboah-Coleman \& Agyire-

Tettey, 2008). This can charge for investments in other, more attractive places.

The effect of the appreciation of the exporter's exchange rate which made the price of the country's products higher. The price increase caused a decrease in export demand because the world market expects lower prices. The appreciation of the exchange rate will have an impact on the price of imported products to be cheaper than the prices before the appreciation. This results in a greater demand for imported goods. Conversely, in the case of price devaluation, the demand for exported goods will increase due to lower prices for exported goods. While the demand for imported goods decreased because the depreciation of the imported goods became higher due to the depreciation of the goods.

Based on a report by the Central Bureau of Statistics (BPS) in 2019 that Indonesia's non-migas exports were still dominated by the processing industry with US $\$ 60,156.9$ million (81.05\%). For example, the weakening of the exchange rate can be important information for export companies. Of course, this is an opportunity for companies to boost the amount of exports that can in turn affect corporate earnings and encourage rising stock prices. From different studies there are differences in the findings, Sakti \& Harun (2013); Bekhet \& Matar (2013); and Antonio et al., (2013) that the exchange rate has a positive relationship with the stock price index. In contrast to the findings of Oktarina, (2017); Artini et al., (2017); and Wei et al., (2019) exchange rates have a negative effect on stock prices.

\section{Interest Rates}

Monetary policy plays a very important role in the economy of a country. A monetary policy that often attracts the attention of stakeholders is interest rates. Interest rates are an attraction for savers, changes in interest rates can be the effect of a shift in investments from the capital market to banks.

In addition, changes in interest rates become a burden for companies, so that this can be the effect of the lower profits obtained, which will further stimulate the fall in stock prices. Kewal (2012) that interest rates affect corporate profits in two ways. First, because interest rates are costs, this shows that the higher the interest rate for loans, the effect on the lower profit earned by the company. Secondly, interest rates have an impact on economic activity, so that it can affect the profits of companies. A fall in net income will lead to a fall in earnings per share and ultimately to a fall in share prices in the market. There are various research results from Oktarina (2017); Artini et al., (2017); Pratama \& Azzis (2018); Mawardi et al., (2019) show that interest rates have a negative effect on stock prices. But Pantas et al., (2019) show that interest rates not effect on stock prices in Indonesia. 


\section{Stock Market Index}

According to Ameer (2006) there are two literatures that show integration between stock markets. First, the economic factors that are most relevant to explaining the phenomenon of correlation between the stock market are related to interest rates, oil prices and other commodity prices. Secondly, openness of the stock market that offers foreign investors benefits from diversification of portfolios in previously closed and segmented stock markets. The effect of stock market integration depends on the size of the recipient country's economy.

Financial openness is often seen as important potential benefits. The ability to use international resources that are accessible through financial openness can also affect investments. Access to world capital markets can increase the chances of investors to diversify portfolios and offer the potential to achieve higher risk-adjusted returns.

Increasing international financial integration has always received much attention because of the importance of a clear understanding and prediction of the relationship between equity returns and the transfer of volatility between equity markets around the world. In particular, the transfer of volatility between international markets is highly relevant for investors as they must constantly monitor and assess changes in stock market relationships to achieve portfolio diversification and the benefits of risk sharing.

The stock price index can reflect the economy of a country, so the influence of the stock markets of these countries can affect the stock markets of other countries such as Indonesia. Mohti et al., (2019) found that there is an integration between the stock markets of developing countries and the US stock market in the long term. Findings from Oktarina (2017); Sihombing \& Rizal (2014); Artini et al., (2017) show that there is a significant positive relationship between the American and Indonesian stock markets. Santos et al., (2019) found that the return of the stock index of developed countries (Brazil, Russia, India, China and South Africa) affected the return index of non-BRICS developing countries (Mexico, Indonesia, Turkey, Iran and Poland).

The findings of Mohti et al., (2019) show that the Indonesian and Japanese stock markets are integrated in the short term. In contrast to the findings of Oktarina, (2017) that the Nikkei 225 Index has a positive effect, while Sihombing \& Rizal, (2014) found a negative relationship between the Nikkei 225 Index and the CSPI. While Tamisari et al., (2016) found no significant relationship between the Japanese and Indonesian stock markets.

Based on the observation of Ahmed \& Huo (2019) that there is an integration between the Chinese stock market and the stock market of Asia-Pacific countries, this indicates that the Asia-Pacific stock market is significantly influenced by good news about the Chinese economy. The

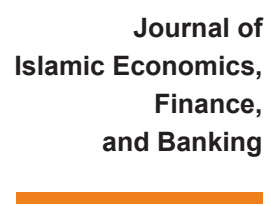

Vol. 4, No. 1, June 2021, pp. 45-58, ISSN p:2622-4755 e:2622-4798 
upward trend in the Chinese stock market is important information for investors to do purchase transactions in the Chinese stock market. The IHTIFAZ - JIEFB findings of Oktarina (2017) and Sihombing \& Rizal (2014) that SSE has a negative impact on Jakarta Composite index. In contrast to the findings of Artini et al., (2017) that there is no relationship between the Chinese and Indonesian stock markets. Santos et al., (2019) discovered that the return of the stock index of developing countries in BRICS (Brazil, Russia, India, China and South Africa) is the return index of non-BRICS developing countries (Mexico, Indonesia, Turkey, Iran and Poland)

The author's motivation in this study is as follows: First, analyse whether macroeconomic variables affect both domestic and global returns on Shariah equity returns in the context of equity markets in developing countries. Secondly, the relationship between domestic and global stock markets can be used by investors to achieve optimum returns.

The focus of this study is therefore to analyse the influence of domestic macroeconomic variables and global stock indices on the Islamic stock index, both long and short term, using the Vector Error Correction Model (VECM).

\section{Methodology}

The type of data used in this study is in the form of monthly time series from May 2011 to July 2019. According to Bungin (2005), secondary data is a form of data obtained from the second source or other sources. Sources of data in this study were obtained from various sources, data from the Indonesian Sharia Stock Index (ISSI) obtained from statistical data on the Indonesia Stock Exchange. Exchange rates and interest rates from Bank Indonesia, Standard \& Poor's 500 Index data from the NYSE, Nikkei 225 Index from JPX, Shanghai Stock Exchange Index from SSE.

For the sampling technique in this study, the saturation sampling technique, which is referred to as the Sugiyono (2014) saturation sampling technique, is a technique for determining the sample when all population members are used as samples. For this reason, the sample that will be used in this study is the monthly time series data of the Indonesian Sharia stock index from May 2011 to July 2019. So, the number of observations is 99 observations.

This study uses a Vector Error Correction Model approach through the following phases: 1) Stationarity test, 2) Optimal lag test, 3) Cointegration test. The following description of the analysis model Error correction model in the long term will be used as follows:

LnISSI $_{t}=\beta_{0}+\beta_{1} L_{n N T_{t}}+\beta_{2} I R_{t}+\beta_{3}$ LnNikkei $_{t}+\beta_{4}$ LnSSE $_{t}+\beta_{5} \operatorname{LnS\& P}_{t}+\varepsilon_{t}$

\section{Short term Models}

$$
\begin{aligned}
\Delta \text { LnISSI }_{t}=\beta_{0} & +\beta_{1} \Delta L n N T_{t}+\beta_{2} \Delta I R_{t}+\beta_{3} \Delta L n N i k k e i_{t}+\beta_{4} \Delta L n S S E_{t} \\
& +\beta_{5} \Delta L n S \& P_{t}+\beta_{6} E C T+\varepsilon_{t}
\end{aligned}
$$


The ISSI variable is the Indonesian Sharia stock index, NT is the exchange rate, IR is the interest rates, LnNikei is the Nikkei 225 index, LnSSE is the Shanghai Stock Exchange index, S\&P is the Standard \& Poor's 500 index, $\beta_{0}$ is the interception, $\beta_{1}-\beta_{6}$ is the coefficient value of each variable, Ln is Natural Logarithm, ECT is Error Correction Term and $\varepsilon$ is Error.

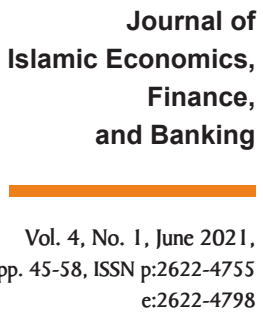

\section{Results and Discussion}

\section{Stationary test}

Table 1 show the results of the unit root test with the ADF method (Augmented Dickey-Fuller), it shows that all variables are not stationary at level. It can be seen that the prob value with a significance level of $5 \%$, then at the level of all ISSI variables, exchange rates, interest rates, Nikkei 225 index, S\&P 500 index, SSE index is not stationary because the $p$-value $>5 \%$. To get all variables they must be stationary, then the unit's root test is performed on the first difference, so that it can be seen that all stationary variables at the first difference with a significance of $<5 \%$.

Table 1. Stationary test results

\begin{tabular}{lcc}
\hline & ADF Test at Level & \\
\hline \multicolumn{4}{c}{ Variable } & t-Statistic & Prob.* \\
\hline LnISSI & -1.802026 & 0.377 \\
\hline LnNT & -1.914261 & 0.324 \\
\hline IR & -1.624921 & 0.466 \\
\hline LnN225 & -1.213598 & 0.666 \\
\hline LnSP500 & -0.531544 & 0.879 \\
\hline LnSSE & -1.924799 & 0.319 \\
\hline & ADF Test at First & \\
\hline LnISSI & -8.864445 & 0.000 \\
\hline LnNT & -10.59147 & 0.000 \\
\hline IR & -6.480936 & 0.000 \\
\hline LnN225 & -9.368018 & 0.000 \\
\hline LnSP500 & -11.82364 & 0.000 \\
\hline LnSSE & -8.164319 & 0.000 \\
\hline
\end{tabular}




\section{Optimal lag test}

Determining the optimum lag is one of the phases in the stationarity IHTIFAZ - JIEFB test. If the lag used in the stationarity test is too small, this causes the residual regression not to represent the white noise process, so that the model cannot correctly estimate the actual error and the coefficient and standard error of the variable cannot be estimated.

Table 2. Optimal Lag Test Results

\begin{tabular}{ccccccc}
\hline Lag & LogL & LR & FPE & AIC & SC & HQ \\
\hline 0 & 331.1678 & NA & $3.17 \mathrm{e}-11$ & -7.146544 & -6.980993 & -7.079755 \\
\hline 1 & 986.0411 & 1208.997 & $3.94 \mathrm{e}-17^{*}$ & $-20.74816 *$ & $-19.58930 *$ & $-20.28063^{*}$ \\
\hline 2 & 1012.112 & 44.69250 & $4.95 \mathrm{e}-17$ & -20.52993 & -18.37776 & -19.66166 \\
\hline 3 & 1044.477 & 51.21568 & $5.50 \mathrm{e}-17$ & -20.45005 & -17.30458 & -19.18105 \\
\hline 4 & 1073.194 & 41.65524 & $6.78 \mathrm{e}-17$ & -20.28998 & -16.15120 & -18.62024 \\
\hline 5 & 1098.846 & 33.82666 & $9.25 \mathrm{e}-17$ & -20.06255 & -14.93046 & -17.99207 \\
\hline 6 & 1131.285 & 38.49916 & $1.14 \mathrm{e}-16$ & -19.98429 & -13.85889 & -17.51307 \\
\hline 7 & 1174.070 & 45.13582 & $1.19 \mathrm{e}-16$ & -20.13341 & -13.01471 & -17.26146 \\
\hline 8 & 1230.323 & $51.92573 *$ & $9.98 \mathrm{e}-17$ & -20.57853 & -12.46652 & -17.30584 \\
\hline
\end{tabular}

Testing the lag optimal using the Final Prediction Error (FPE) criteria, Akaike Information Criterion (AIC), Schwarz Information Criterion (SIC), Hannan-Quinn Information Criterion (HQ). The optimum lag test results show that the criteria for FPE, AIC, SIC, HQ are shown in lag 1.

\section{Cointegration Test}

The purpose of the co-integration test is to determine the possibility of a long-term relationship between the dependent variable and the independent variable. The approach used for the cointegration test is Joahansen's Multivariate Cointegration Test.

Table 3. Cointegration Test Results

\begin{tabular}{ccccc}
\hline \multicolumn{5}{c}{ Unrestricted Cointegration Rank Test (Trace) } \\
\hline Hypothesized & Eigenvalue & Trace & 0.05 & \\
No. of CE(s) & & Statistic & Critical Value & \\
\hline None ${ }^{*}$ & 0.304349 & 105.7553 & 95.75366 & 0.0086 \\
\hline At most 1 & 0.239306 & 70.55329 & 69.81889 & 0.0436 \\
\hline At most 2 & 0.205396 & 44.02145 & 47.85613 & 0.1095 \\
\hline At most 3 & 0.112736 & 21.71999 & 29.79707 & 0.3143 \\
\hline At most 4 & 0.078089 & 10.11761 & 15.49471 & 0.2718 \\
\hline At most 5 & 0.022737 & 2.230912 & 3.841466 & 0.1353 \\
\hline
\end{tabular}

Source: Eviews 9

Trace test indicates 2 cointegrating eqn(s) at the 0.05 level 
Based on the results of tests with the Multivariate Cointegration Test from Joahansen in table 3 show that co-integration with Trace shows that the variables used in this research model have a co-integration relationship. Because of cointegration in the research variables, estimation techniques can therefore use the Vector Error Correction Model (VECM).

\section{Vector Error Correction Model}

The results of the VECM test are shown in Table 4 below:

Table 4. VECM Test Results

\begin{tabular}{|c|c|c|c|}
\hline \multicolumn{4}{|c|}{ Long term } \\
\hline Cointegrating Eq: & Coefficient & $\mathrm{t}-_{\text {statistic }}$ & $t_{\text {table }}$ \\
\hline IR & -0.071738 & 3.80991 & \\
\hline LogNT & 1.086397 & 3.12100 & \\
\hline LogSSE & -0.510377 & 4.50744 & 1.98580 \\
\hline LogN225 & 0.034251 & 0.14181 & \\
\hline LogSP500 & 0.109773 & 2.35605 & \\
\hline $\mathrm{C}$ & 0.153269 & & \\
\hline \multicolumn{4}{|c|}{ Short term } \\
\hline Error Correction: & Coefficient & $\mathrm{t}-_{\text {statistic }}$ & $t_{-}{ }_{\text {table }}$ \\
\hline CointEq1 & -0.225223 & 5.62507 & \\
\hline LogISSI(1) & 0.168796 & 1.33769 & \\
\hline LogISSI(2) & 0.038810 & 0.30691 & \\
\hline $\operatorname{IR}(1)$ & -0.012746 & 0.69033 & \\
\hline $\operatorname{IR}(2)$ & -0.002999 & 0.16048 & \\
\hline LogNT(1) & 0.010484 & 0.05185 & \\
\hline LogNT(2) & -0.119675 & 0.64286 & 1.98580 \\
\hline LogSSE(1) & 0.109080 & 1.80873 & \\
\hline $\operatorname{LogSSE}(2)$ & 0.194625 & 1.19720 & \\
\hline $\operatorname{LogN225(1)}$ & 0.062604 & 0.65092 & \\
\hline LogN225(2) & 0.027427 & 0.28905 & \\
\hline LogSP500(1) & -0.117407 & 0.79049 & \\
\hline LogSP500(2) & -0.277814 & 1.81402 & \\
\hline $\mathrm{C}$ & 0.005317 & 1.36961 & \\
\hline
\end{tabular}

Source: Eviews 9

Note: sig $\left(\mathrm{t}^{-}{ }_{\text {statisticc }}>\mathrm{t}_{\text {table }}\right)$, no sig $\left(\mathrm{t}_{\text {}_{\text {statistic }}}<\mathrm{t}_{\text {table }}\right)$

\section{DISCUSSION}

The effect of the interest rates on the Indonesian Sharia Stock Index

Interest rates have a significant negative effect on Indonesia Sharia Stock Index, because the $t^{{ }_{\text {statistic }}}$ value (3.80991) $>\mathrm{t}^{{ }_{\text {table }}}$ (1.98580) with 
the coefficient value $(-0.071738)$. The interest rate variable has an opposite effect on ISSI. These findings are consistent with research by IHTIFAZ - JIEFB Oktarina (2017); Artini dkk., (2017); Pratama \& Azzis (2018); Mawardi dkk., (2019) show that interest rates have a negative impact on stock prices. An increase in interest rates can increase the burden on the company, so that it can reduce the profitability of the company, which can further reduce share prices.

The rise in interest rates also encouraged investors to move their investment funds from the capital market to banking instruments. When investors withdraw massive amounts of money from the capital market from banks, this can have an impact on the fall in stock prices. Conversely, low interest rates ensure that investors divert their investments from banks to the stock market. This shows that the role of interest rates for investors is still an option to take advantage of various investment instruments that are closely related to interest rates such as savings and bank deposits.

Moreover, according to Kewal (2012) interest rates affect corporate profits in two ways. First, because interest rates are costs, this shows that the higher the interest rate for loans, the effect on the lower profit earned by the company. Secondly, interest rates have an impact on economic activity, so that it can influence the profits of companies. A fall in net income will lead to a fall in earnings per share and ultimately to a fall in share prices in the market.

An increase in high interest rates can have an impact on financing costs, so that due to changes in high interest rates, an increasing burden may be incurred by the company to pay bank capital costs, the increase in capital costs will influence earned earnings and then prices will affect company stock. This is in line with research by Kussuma, Surachim, \& Tanuatmodjo, (2016)that the company's ability to generate profits influences stock prices. This means that the greater the company's ability to generate profits will affect the movement of stock prices, as it will allow investors to invest in the company (buy shares).

\section{The effect of the exchange rate on the Indonesian Sharia Stock Index}

The exchange rate has a significant positive effect on ISSI, because the $t_{-}{ }_{\text {statistic }}$ value $(3.12100)>t^{-}{ }_{\text {table }}(1.98580)$ with a coefficient value (1.086397). The exchange rate variable has a direct effect on Indonesia Sharia Stock Index. The results of this study are in line with Sakti \& Harun, (2013); Bekhet \& Matar, (2013); and Antonio et al., (2013) that the exchange rate has a positive effect on the stock price index. In contrast to the findings of Oktarina, (2017); Artini et al., (2017); and dan Wei et al., (2019) showing that the exchange rate has a negative effect.

The positive effect of the exchange rate shows that if the exchange rate weakens (depreciation), it will affect the increase in exports. 
Because the price of exported goods is relatively cheaper in the eyes of international buyers. Companies whose products are based on export will benefit from the weakening of the exchange rate to increase the productivity of exported goods. So, increasing productivity will affect the profit of the company.

Based on the results of the research by Kussuma, Surachim, \& Tanuatmodjo (2016), the company's ability to generate a profit has an impact on stock prices. This means that the greater the company's ability to generate profits will affect the movement of stock prices, as it will allow investors to invest in the company (buy shares). The effect of the weakening of the exchange rate will be positively answered by the stock price and will generally affect the sharia stock price index.

\section{The effect of the Nikkei 225 index on the Indonesian Sharia Stock Index}

The Nikkei 225 index has an insignificant negative effect on the ISSI return because the t-statistical value $(0.50663)<\mathrm{t}$-table $(1.98580)$. The results of this study are in line with the findings of Tamisari dkk., (2016) that there is no significant relationship between the Japanese and Indonesian stock markets. Unlike the findings of Oktarina, (2017) that the Nikkei 225 Index has a positive effect, while Sihombing \& Rizal, (2014) found that there is a negative relationship between the Nikkei 225 Index and the compound stock price index.

The insignificant influence between the Nikkei 225 Index and the Indonesian Sharia Stock Index shows that although Japan and Indonesia have formed economic cooperation in trade and investment, they are often referred to as the IJEPA (Indonesia-Japan Economic Partnership Agreement), but this indicates not on stock market integration, currently only the Indonesian trade sector has a lot of access to Japan, while the investment sector is still very minimal.

\section{The effect of the Standard \& Poor's 500 index on the Indonesian Sharia Stock Index}

The Standard \& Poor's 500 index has a significant positive effect on the Indonesian Sharia Stock Index, because the t- ${ }_{\text {statistic }}$ value (4.32546)> $\mathrm{t}_{\text {table }}(1.98580)$ with a coefficient value $(0.109773)$. The results of this study are in line with the results of the study by Oktarina, (2017) and Artini et al., (2017) which show that there is an influence between the US stock index and the Indonesian stock index.

The United States is a country that has a major impact on the world's economy, Indonesia is no exception to the economy of the United States (Oktarina, 2017). The role of the American economy is important information for developing countries such as Indonesia. All movements in the US economy will therefore have both direct and indirect consequences, in particular in relation to the stock markets of the two countries. 
In addition, Mohti et al., (2019) found a long-term integration between the stock markets of developing countries with the stock IHTIFAZ - JIEFB markets of developed countries in the United States. Asian developing countries such as Indonesia are export countries for the American market. This is why the development of Asian stock markets such as Indonesia tends to move along with the US market.

\section{The effect of the Shanghai Stock Exchange index on the Indonesian Sharia Stock Index}

The Shanghai Stock Exchange Index has a significant negative effect on ISSI returns because the $t_{-}{ }_{\text {statistic }}$ value $(3.2659)>t_{\text {table }}$ (1.98580) with a coefficient value $(-0.510377)$. Shanghai Stock Exchange Index variable has the opposite effect with ISSI returns. The results of this study are in line with the results of the study by Oktarina (2017) and Sihombing \& Rizal (2014). However, the findings of Artini et al., (2017) show that there is no influence between the Chinese stock market and the Indonesian stock market.

The negative impact between the SSE index and ISSI indicates that although trade relations between Indonesia and China have developed increasingly along with the signing of the ASEAN-China Free Trade Agreement (ACFTA), this was not followed by the strengthening of stock market relationships between the two countries (Oktarina, 2017). This also shows that there is competition between the two markets, so that investors are used to diversifying their portfolios.

The observations of Ahmed \& Huo (2019) also showed that the Chinese stock market had a significant impact on the financial markets in Asia-Pacific, mainly influenced by the good news from the Chinese economy. So that the movement of the rising trend in the Chinese stock market becomes a very important buy signal for foreign investors.

\section{CONCLUSION}

The movement of the Islamic stock index is inextricably linked to the influence of changes in domestic macroeconomic conditions. Interest rates are monetary policies that have a significant negative effect on changes in Sharia stock prices, as well as changes in exchange rates can affect companies that trade internationally.

In addition to domestic macroeconomic factors, sharia prices are influenced by stock market movements from countries that have great power over the global economy. The SSE index has a negative effect, as the presence of good employees from China's economic growth becomes a signal for foreign investors to optimize profits from international portfolios.

The US stock market has the same direction as the movement of the Islamic stock market, because Indonesia is one of the countries that follows the pattern of the US economy. Although the Japanese stock 
market has no significant effect, because at present only the Indonesian trading sector has much access to Japan, while this is still very minimal for the investment sector.

\section{ACKNOWLEDGMENT}

The authors would like to thank all the lecturers Master Science of Islamic Economic at Airlangga University who helped provide input on this paper, and then authors would like to thank the editors and reviewers for helpful comments.

\section{REFERENCES}

\section{Journal}

Ahmed, A. D., \& Huo, R. (2019). Impacts of China's crash on AsiaPacific financial integration : Volatility interdependence, information transmission and market co-movement. Economic Modelling, 79, 28-46. https://doi.org/10.1016/j.econmod.2018.09.029

Ameer, R. (2006). Integration of the South and East Asian Stock Markets : How Long to Go ? Journal of Financial Reporting \& Accounting, 4 (1), 61-102.

Antonio, M. S., Hafidhoh, \& Fauzi, H. (2013). The Islamic Capital Market Volatility : A Comparative Study Between In Indonesia And Malaysia. Bulletin of Monetary, Economics and Banking, 377-400.

Artini, L. G. S., Aryati, N. T., Lestari, P. V., \& Darmayanti, N. P. A. (2017). Analisis Fundamental Makro dan Integrasi Pasar Sahan Duni dengan Bursa Efek Indonesia. Jurnal Manajemen, Strategi Bisnis Dan Kewirausahaan, 11 (2), 128-135.

Bekhet, H. A., \& Matar, A. (2013). Co-integration and causality analysis between stock market prices and their determinates in Jordan. Economic Modelling, 35, 508-514. https://doi.org/10.1016/j. econmod.2013.07.012

Kewal, S. S. (2012). Pengaruh inflasi, suku bunga, kurs, dan pertumbuhan pdb terhadap indeks harga saham gabungan. Jurnal Economia, 8 (1), 53-64.

Kussuma, P., Surachim, A., \& Tanuatmodjo, H. (2016). Dampak Tingkat Profitabilitas dan Nilai Pasar Pada Pergerakan Harga Saham PT. Prasidha Aneka Niaga Tbk. Journal of Business Management Education, 1(2), 97-103.

Kyereboah-Coleman, A., \& Agyire-Tettey, K. F. (2008). Impact of macroeconomic indicators on stock market performance: The case of the Ghana Stock Exchange. Journal of Risk Finance, 9(4), 365-378. https://doi.org/10.1108/15265940810895025

Mawardi, I., Widiastuti, T., \& Sukmaningrum, P. S. (2019). The Impact of Macroeconomic on Islamic Stock Prices : Evidence from Indonesia. 
KnE Social Sciences, 499-509. https://doi.org/10.18502/kss. v3i13.4226

IHTIFAZ - JIEFB

Mohti, W., Dionisio, A., Vieira, I., \& Ferreira, P. (2019). Regional and global integration of Asian stock markets. Research in International Business and Finance, 50, 357-368. https://doi.org/10.1016/j. ribaf.2019.06.003

Oktarina, D. (2017). Pengaruh beberapa indeks saham global dan indikator makroekonomi terhadap pergerakan IHSG. Journal of Business and Banking, 5(2016), 163-182. https://doi.org/10.14414/ jbb.v5i2.701

Pantas, P. E., Nafik, M., Munir, M., \& Wahyudi, R. (2019). Cointegration of Stock Market and Exchange Rate in Indonesia. Journal of Islamic Economics, Finance, and Banking, 2(2), 125-135.

Pratama, Y. C., \& Azzis, A. (2018). Macroeconomic Variables , International Islamic Indices, and The Return Volatility in Jakarta Islamic Index. Al-Iqtishad, 10 (95), 171-188.

Sakti, M. R. P., \& Harun, M. Y. (2013). Relationship between Islamic Stock Prices and Macroeconomic Variables: Evidence from Jakarta Stock Exchange Islamic Index. Global Review of Islamic Economics and Business, 1(1), 71-84.

Santos, C. M. dos, Gaio, L. E., Junior, T. P., \& Cicconi, E. G. (2019). Interdependence and contagion in the period of crisis. International Journal of Emerging Markets, 14 (5), 1013-1031. https://doi. org/10.1108/IJOEM-05-2018-0216

Sihombing, P., \& Rizal. (2014). Pengaruh Indeks Saham Global Dan Kondisi Makro Indonesia Terhadap Indeks Harga Saham Gabungan Bursa Efek Indonesia. Media Ekonomi, 22(2), 133-150.

Tamisari, M. D., Oktaviani, R., \& Hakim, D. B. (2016). Stock Market Integration of Asean +6 on Indonesia Composite Stock Price Index (JKSE). International Journal of Business and Management Invention, 5(2), 1-7.

Wei, Y., Qin, S., Li, X., Zhu, S., \& Wei, G. (2019). Oil price fluctuation, stock market and macroeconomic fundamentals: Evidence from China before and after the financial crisis. Finance Research Letters, 30 (February), 23-29. https://doi.org/10.1016/j.frl.2019.03.028

\section{Texbooks}

Bungin, B. (2005). Metodologi Penelitian Kuantitatif. Jakarta: Kencana. Murhadi, W. R. (2009). Analisis Saham Pendekatan Fundamental. Jakarta: Indeks.

Sugiyono. (2014). Metode Penelitian Kuantitatif Kualitatif dan R\&D. Bandung: Alfabeta. 